[Radiocarbon, Vol. 14, No. 2, 1972, P. 331-335]

\title{
INSTITUTE OF GEOLOGICAL SCIENCES \\ RADIOCARBON DATES III
}

E. WELIN, L. ENGSTRAND, and S. VACZY

Radioactive Dating Laboratory, S-10405, Stockholm 50, Sweden*

This date list was compiled by the Institute of Geological Sciences (U.K.) incorporating data supplied under contract by E. Welin, Radioactive Dating Laboratory, Stockholm. Unless otherwise stated, age figures are in $\mathrm{C}^{14}$ years before A.D. 1950. The half-life of $\mathrm{C}^{14}$ is taken as 5568 years and the error, based on counting statistics of sample, background, and modern, is given as one standard deviation. Correction for $\mathrm{C}^{13} / \mathrm{C}^{12}$ fractionation has not been made.

\section{IGS-C14/42 (St 3402) Westward Ho: Devon}

Wood fragments from peat bed exposed by exceptional March 1970 on Westward March 1970 on Westward Ho! beach $\left(51^{\circ} 2^{\prime} \mathrm{N}\right.$ Lat, $4^{\circ} 14^{\prime} \mathrm{W}$ Long, Grid Ref. SS 4319 2958). Coll. 1970 and subm. by B. J. Williams, Inst. Geol. Sciences. Comment (B.J.W.): wood from roots in situ in peat bed $0.6 \mathrm{~m}$ thick, $2 \mathrm{~m}$ below high water mark. Part of submerged forest (Rogers, 1908) drowned by Flandrian transgression.

\section{Sugarloaf Hill series, Folkestone, Kent}

Samples from series of calcareous slope and spring deposits up to 3 $m$ thick in a chalk valley near Folkestone $\left(51^{\circ} 5^{\prime} \mathrm{N}\right.$ Lat, $1^{\circ} 10^{\prime} \mathrm{E}$ Long, Grid Ref. TR 220 379). Coll. 1969 and subm. by M. P. Kerney and C. Turner. General stratigraphy as follows:

4. Brown stony chalk silt (hillwash)

3. Pale calcareous silt with abundant algal nodules (tufaceous)

2. Dark gray organic calcareous silt with much wood debris

1. Pale chalk silt and gravel on Gault Clay

\section{IGS-C14/48. (St 3410)}

$7500 \pm 100$

From seam of organic silt in (3).

IGS-C14/46. (St 3411)

5550 B.C.

Wood fragments and hazel nuts from upper part of

$8980 \pm 100$ 7030 B.C.

\section{IGS-C14/47. (St 3395)}

Wood fragments and hazel nuts from lower part of (2).

\section{IGS-C14/49. (St 3409)}

\section{Small wood fragments (birch) from (1).}

* Published by permission of the Director, Institute of Geological Sciences, Exhibition Road, London SW7. The Institute is a contracting agency, not a dating laboratory, yet IGS at London is the "author" when needed for inter-laboratory
communication. 
General Comment (M.P.K.): the matrix of C14/49 yielded a molluscan fauna and macroscopic plant remains of Late Weichselian (Late-glacial) character. The date from this sample is clearly too young, but sample was very small and probably insufficient for dating.

A detailed analysis of the non-marine Mollusca, macroscopic plant remains and pollen of beds (2), (3), and (4) is being undertaken. Preliminary results indicate that beds (2) and (3) extend from Zone $\mathrm{V}$ to Zone VIa of the Flandrian. Dates of Samples $46-48$ agree with expectations.

\section{IGS-C14/52. (St 3408) Bridgwater, Somerset}

$4200 \pm 100$

Peat from $5.79 \mathrm{~m}$ below surface in borehole $\left(51^{\circ} 07^{\prime} \mathrm{N}\right.$ Lat, $2^{\circ} 59^{\prime}$ W Long, Grid Ref. ST 3115 3504), near Huntworth and close to R. Parrett. Coll. 1970 and subm. by Alfred Whittaker, Inst. Geol. Sciences. Comment (A.W.): peat, $1.5 \mathrm{~m}$ thick, rests directly on weathered Keuper Marl, at location close to margin of alluvium.

\section{IGS-C14/53. (St 3407) Highbridge, Somerset}

$8365 \pm 100$

W Long, Grid Ref. ST 3301 4699) at Walrow. Coll. 1970 and subm. by Alfred Whittaker. Comment (A.W.): represents deeper peat underlying parts of Somerset Levels.

IGS-C14/54. (St 3404) Kirmington, Lincolnshire

$>40,000$

Peat from $5.5 \mathrm{~cm}$ bed at ca. $5.75 \mathrm{~m}$ below ground level (but exposure may be in slipped material) in old brickpit $\left(53^{\circ} 36^{\prime} \mathrm{N} \mathrm{Lat,} 0^{\circ} 20^{\prime}\right.$ W Long, Grid Ref. TA 1029 1161) on NW outskirts of Kirmington Village. Coll. 1970 and subm. by E. G. Smith, Inst. Geol. Sciences. Comment (E.G.S.): infinite date supports pre-Devensian age (Watts, 1959; Boylan, 1966).

\section{Pett Level series, Sussex}

Material from submerged forest outcrop on foreshore between median high and low water marks of ordinary tides at Pett Level, near Hastings, Sussex. In situ tree boles and recumbent trunks rest on $0.6 \mathrm{~m}$ peat bed which overlies soft gray silty clay seen to be $>1 \mathrm{~m}$ thick, $\left(50^{\circ} 53^{\prime} \mathrm{N}\right.$ Lat, $0^{\circ} 42^{\prime} \mathrm{E}$ Long, Grid Ref. TQ 8995 1400). Coll. and subm. 1970 by E. R. Shephard-Thorn, Inst. Geol. Sciences.

\section{IGS-C14/55. (St 3400)}

$5205 \pm 105$

Wood from in situ tree stump.

3255 в.c.

\section{IGS-C14/56. (St 3405)}

$5300 \pm 100$

Peat (soil from beneath tree stump).

General Comment (E.R.S.-T.): dates for submerged forest are ca. 2000 yr earlier than those available for near-surface peats of Romney Marsh 
at inland sites (NPL 23/24 (Callow et al., 1964) and IGS-C14/13 (Welin, 1971), with which the forest bed may be laterally continuous. Formation of the peat-forest bed possibly commenced to seaward in the lee of an early shingle spit of the Dungeness complex and migrated landwards with rising sea level of the mid- to late-Holocene (Flandrian transgression), forming a diachronous layer. The difference in the 2 dates suggests a minimum endurance of the forest bed at this locality of $100 \mathrm{yr}$.

\section{IGS-C14/57. (St 3406) Peterborough, $\quad 4460 \pm 105$ Northamptonshire 2510 B.c.}

Woody peat from depth $6.15 \mathrm{~m}$ in a borehole $\left(52^{\circ} 34^{\prime} \mathrm{N}\right.$ Lat, $0^{\circ} 15^{\prime}$ W Long, Grid Ref. TL 1823 9827). Peat lies within $0.55 \mathrm{~m}$ of base of alluvial clay sequence. Coll. 1970 and subm. by Albert Horton, Inst. Geol. Sciences. Comment (A.H.): dates early stage of accumulation of R. Nene alluvium.

\section{IGS-C14/58. (St 3398) Peterborough,} Northamptonshire

$3475 \pm 100$

1525 B.C.

Wood fragments from depth $6.15 \mathrm{~m}$ in a borehole $\left(52^{\circ} 34^{\prime} \mathrm{N}\right.$ Lat, $0^{\circ} 15^{\prime} \mathrm{W}$ Long, Grid Ref. TL 1812 9844). Coll. 1970 and subm. by Albert Horton. Wood from peaty layer $0.25 \mathrm{~m}$ above base of alluvial clay sequence. Comment (A.H.): deposition of Nene alluvium may have commenced later than at previous sample point (IGS-C14/57).

\section{IGS-C14/59. (St 3397) Elloughton Beck, $\quad 3905 \pm 105$ Yorkshire \\ 1955 B.C.}

Wood fragment from organic sand, silt, and clay resting on boulder clay in Elloughton Beck (53 $44^{\prime} \mathrm{N}$ Lat, $0^{\circ} 34^{\prime} \mathrm{W}$ Long, Grid Ref. SE 9476 2684) at Elloughton W of Hull. Coll. 1970 and subm. by G. D. Gaunt, Inst. Geol. Sciences. Comment (G.D.G.): date, which is within range of Sub-Boreal period, indicates deposit is comparable in age to other organic deposits in region (Wright and Churchill, 1965; Hulme and Beckett, in press). Pollen analysis of the deposit is in progress.

\section{Harcourt series, Shropshire}

Rootlets and tree-trunk from early postglacial lake sequence in the Mad Brook Valley at Telford, Shropshire, seen in a temporary trench sec. (52 $38^{\prime} \mathrm{N}$ Lat, $2^{\circ} 26^{\prime} \mathrm{W}$ Long, Grid Ref. SJ 7084 0444). Coll. 1970 and subm. by R. J. O. Hamblin. The succession at this point is as follows:

4. Alluvium, mottled clay

3. Coarse sands, cross-bedded with peaty bands, rootlets in growth positions; represents final infilling of lake

2. Lacustrine clay; unbedded, sparsely pebbly, very tenacious; rootlet bed at upper surface

1. Boulder clay 
IGS-C14/61. (St 3401)

$9410 \pm 120$

Rootlet bed growing in top of lacustrine clay (2), truncated by cross-

7460 в.c. bedded sands.

IGS-C14/60. (St 3392)

$3180 \pm 100$

Tree-trunk lying within cross-bedded sand unit (3).

IGS-C14/62. (St 3389)

1230 B.c.

Rootlet bed growing in top of cross-bedded sand unit (3), truncated by alluvium.

General Comment (R.J.O.H.): Sample 61 gives a date at the end of initial lake phase, after deposition of clay. Sample 60 gives a date within deposition of the succeeding sands, and 62 post-dates infilling of lake but predates alluvial deposition.

Felted wood and reed peat at depth 6.7 to $7.1 \mathrm{~m}$ in borehole $\left(52^{\circ}\right.$ $45^{\prime} \mathrm{N}$ Lat, $0^{\circ} 10^{\prime} \mathrm{W}$ Long, Grid Ref. TF 2370 1932). Coll. 1970 and subm. by Albert Horton, Inst. Geol. Sciences. Comment (A.H.): dates assoc. clay sequence which extends to depth $9.1 \mathrm{~m}$ as Holocene Fen Clay.

\section{IGS-C14/65. (St 3399) Wakefield, Yorkshire 635 в.c. \\ IGS-C14/66. (St 3388) Wakefield, Yorkshire}

below alluvial clay of $\mathrm{R}$. Calder in gravel pit $\left(53^{\circ} 40^{\prime} \mathrm{N}\right.$ Lat, $01^{\circ} 29^{\prime}$ W Long, Grid Ref. SE 3329 1874). Coll. 1970 by G. D. Gaunt and subm. by A. W. Woodland, Inst. Geol. Sciences. Comment (A.W.W. and G.D.G.): date contrasts with that $(4280 \pm 100$ B.P.) from a wood fragment from equivalent sand and gravel in adjacent Aire Valley and supports conclusions based on pollen analysis that the post-Devensian (postWeichselian) sand and gravel in the 2 valleys range in age from Boreal to Sub-Atlantic (Bartley, 1964; Gaunt et al., 1970).

IGS-C14/67. (St 3482/3483) Outer and Inner $>40,000$

Samples from drag-line dyke operations (by Cayman Govt. Mosquito Research and Control Unit) on W coast of North Sound, Grand Cayman, $2 \mathrm{~km} \mathrm{~N}$ of airstrip $\left(19^{\circ} 18^{\prime} \mathrm{N}\right.$ Lat, $81^{\circ} 21^{\prime} \mathrm{W}$ Long, Grid Ref. UTM Zone 17 Q, NM 620 350). From Ironshore Formation which consists of poorly sorted, unconsolidated chalky limestones, known locally as "marls" (Matley, 1926; Richards, 1955). They contain a small silt-and sand-sized fraction, plus cobble-sized pieces of coral, and abundant and well preserved mollusks. The Ironshore formation lagoonal facies deposit has a crystalline case hardened surface. Specimens from near present day sea 
level. Coll. 1970 by M. E. C. Giglioli; id. by C. P. Nuttall (Brit. Mus. Nat. Hist.); subm. by M. A. Brunt, Directorate Overseas Surveys. Comment (M.A.B.): shells [Codakia orbicularis (Linné)] from unconsolidated limestone (Rehder, 1962); apparently largely recrystallized and calcreted, suggesting considerable bicarbonate exchange and replacement; traces of green algae noted after prolonged cleaning. Inner and outer portions of shells gave same age, and indicate material is too old to be within range of dating.

REFERENCES

Partley, D. D., 1964, Pollen analysis of organic deposits in the Halifax region: Naturalist, Hull, p. 77-87.

Boylan, P. J., 1966, The Pleistocene deposits of Kirmington, Lincolnshire: Mercian Geologist, v. 1, p. 339-350.

Callow, W. J., Baker, M. J., and Pritchard, D. H., 1964, National Physical Laboratory radiocarbon measurements II: Radiocarbon, v. 6, p. 25-30.

Gaunt, G. D., Coope, G. R., and Franks, J. W., 1970, Quaternary deposits at Oxbow opencast coal site in the Aire valley, Yorkshire: Yorkshire Geol. Soc. Proc., v. 38, p. $175-200$.

Hulme, P. D. and Beckett, S. C., Pollen analysis of the Faxfleet peats: East Yorkshire Field Studies, in press.

Matley, C. A., 1926, The geology of the Cayman Islands (British West Indies): Geol. Soc. London Quart. Jour., v. 82, p. 352-387.

Rehder, H. A., 1962, The Pleistocene mollusks of Grand Cayman Island, with notes on the geology of the island: Jour. Palaeontology, v. 36, p. 583-585.

Richards, H. G., 1955, The geological history of the Cayman Islands: Acad. Nat. Sci. Philadelphia Notulae Naturae, no. 284, 11 p.

Rogers, I., 1908, On the submerged forest at Westward Ho!, Bideford Bay: Rept. Devon Assoc. Adv. Sci., v. 40, p. 249-259.

Watts, W. A., 1959, Pollen spectra from the interglacial deposits at Kirmington, Lincolnshire: Yorkshire Geol. Soc. Proc., v. 32, p. 145-151. Welin, E., Engstrand, L., and Vaczy, S., Institute of Geological Sciences radiocarbon
dates I: Radiocarbon, v. 13, p. 26-28.

Wright, E. V. and Churchill, D. M., 1965, The boats from North Ferriby, Yorkshire, England, with a review of the origins of the sewn boats of the Bronze Age:
Prehist. Soc. Proc., v. 31, p. 1-24. 